\title{
Location on the Escherichia coli Genome of a Gene Specifying $O$-Acetylserine (Thiol)-lyase
}

\author{
By A. BORONAT, $\dagger$ P. BRITTON, M. C. JONES-MORTIMER, * \\ H. L. KORNBERG, LYNNE G. LEE, D. MURFITT AND F. PARRA§ \\ Department of Biochemistry, University of Cambridge, Tennis Court Road, \\ Cambridge CB2 1QW, UK
}

(Received 14 July 1983; revised 5 October 1983)

\begin{abstract}
The plasmid pAB65, derived from a specialized transducing phage carrying DNA from about $52 \mathrm{~min}$ on the Escherichia coli genome, coded for two polypeptides of $M_{\mathrm{r}}$ approx. 34000 . The expression of one was regulated by cyst(e)ine and the cysB gene product and the other by the cys $B$ gene product only. One of these polypeptides was a subunit of $O$-acetylserine (thiol)-lyase (EC 4.2.99.8); the other, associated with the $E$. coli membrane, was the N-terminus of the product of the $\lambda$ ben gene. The pattern of peptide synthesis directed by plasmids carrying smaller DNA fragments indicated that the gene for $O$-acetylserine (thiol)-lyase was transcribed clockwise. The spectrum, amino acid composition and subunit number of the enzyme were determined. The enzyme appears homologous with the Salmonella typhimurium cysK gene product. This provides further evidence for the inversion of this region of the genome.
\end{abstract}

\section{INTRODUCTION}

Becker $e$ al. (1969) have shown that $O$-acetylserine (thiol)-lyase (OASL; EC 4.2.99.8, previously known as $O$-acetylserine sulphydrylase A, OASS-A), isolated from Salmonella typhimurium, is a protein of $M_{\mathrm{r}} 68000$ and is composed of two identical subunits of $M_{\mathrm{r}} 34000$. The subunit of OASL is the product of the cys $K$ gene. Addition of cyst(e)ine to cultures of $S$. typhimurium and Escherichia coli represses the synthesis of OASL (Kredich \& Tomkins, 1966; Jones-Mortimer, 1968) and the expression of the cysteine biosynthetic enzymes requires a positive regulator that is specified by the $c y s B^{+}$gene (Spencer et al., 1967; Jones-Mortimer, 1968; Kredich, 1971; Wiater et al., 1982). The cys $K$ gene maps at about $52 \mathrm{~min}$ on the genomes of $E$. coli and of $S$. typhimurium (Fimmel \& Loughlin, 1977; Wiater \& Hulanicka, 1979; Hulanicka \& Klopotowski, 1972; Hulanicka et al., 1974).

In an attempt to refine the genetic map in this region of the $E$. coli genome we have subcloned DNA from the specialized transducing phage $\lambda J M 29$, which carries the wild-type alleles of the gsr, ptsH, iex, cys Z genes and parts of the ptsI gene (Parra et al., 1983a; Britton et al., 1983). Since in UV-irradiated host cells containing the $\lambda$ repressor protein expressed from the $\lambda \mathrm{cI}^{+}$ plasmid pKB280, the phage expressed polypeptides of $M_{\mathrm{r}} 9000,21000,23000,33000,47000$ and 49000 (Britton et al., 1982), it was possible that the polypeptide of $M_{\mathrm{r}} 33000$ might be a subunit of OASL and, hence, that $\lambda \mathrm{JM} 29$ and plasmids subcloned from it also carried the cys $K$ gene. We show here that OASL is specified by DNA approximately $2 \mathrm{~kb}$ anticlockwise from the $p t s I$ gene,

† Present address : Centro de Biología Molecular, Universidad Autónoma de Madrid, Canto Blanco, Madrid34, Spain

¥ Present address: Agricultural Research Council Institute for Research on Animal Diseases, Compton, $\mathrm{Nr}$ Newbury, RG16 0NN, UK

$\S$ Present address: Departamento de Bioquímica, Facultad de Medicina, Universidad de Oviedo, Oviedo, Spain

Abbreviations: LB, Luria broth; OASL, $O$-acetylserine (thiol)-lyase; OASS-A, $O$-acetylserine sulphydrylase A. 
by a gene that is transcribed clockwise. We present evidence for the similarity of the $E$. coli and $S$. typhimurium enzymes. We believe the $E$. coligene specifying OASL to be homologous to the $S$. typhimurium cys $K$ gene.

\section{METHODS}

Strains and materials. The genotypes of the bacterial strains, plasmids and $\lambda$ phage used are listed in Table 1 . The source and grade of chemicals used are as listed by Britton et al. (1982). The minimal medium was that of Ashworth \& Kornberg (1966).

Purification and characterization of plasmid DNA. The plasmid-containing strains were grown in $50 \mathrm{ml}$ Luria broth (LB) containing $100 \mu \mathrm{g}$ ampicillin $\mathrm{ml}^{-1}$. Plasmid DNA was amplified by adding chloramphenicol $\left(170 \mu \mathrm{g} \mathrm{ml} \mathrm{l}^{-1}\right)$ to the cultures and incubating them at $37^{\circ} \mathrm{C}$ for $18 \mathrm{~h}$. The amplified plasmid DNA was prepared as described by Birnboim \& Doly (1979), followed by phenol/chloroform extraction and treatment with RNAase; it was analysed by agarose gel electrophoresis after restriction endonuclease digestion, as described by Boronat $e t$ al. (1982) and Britton et al. (1983). Plasmid DNA was stored in $10 \mathrm{mM}$-Tris/1 mM-EDTA buffer, $\mathrm{pH} 7.5$, at $4^{\circ} \mathrm{C}$ and its concentration was determined by measurement of the $A_{260}$, assuming that an $A_{260}$ of 1.0 is equivalent to $50 \mu \mathrm{g} \mathrm{ml} \mathrm{I}^{-1}$ (Davis et al., 1980).

Construction of the recombinant plasmids. Plasmid pAB15 was constructed, using DNA subcloned from the specialized $\lambda$ transducing phage $\lambda J M 29$, as described by Lee et al. (1982). Construction of plasmid pAB65 was also as described by Lee et al. (1982), the other plasmids were constructed as shown in Fig. 1. (The DNA fragments carried by the new plasmids are shown in Fig. 5.) The buffer systems used for the digestions were as described by Davis et al. (1980) and any enzymes inactivated by heating to $70^{\circ} \mathrm{C}$ for $5 \mathrm{~min}$. Ligation reactions were carried out by adding an equal volume of a freshly prepared solution, at pH 7.4, containing $2 \mathrm{mM-ATP}, 20 \mathrm{mM}-\mathrm{DTT}, 10 \mathrm{mM}-$ Tris/ $\mathrm{HCl}, 10 \mathrm{mM}-\mathrm{NaCl}$ and $10 \mathrm{mM}-\mathrm{MgCl}_{2}$ to the digested DNA solutions, adding 500 units T4 DNA ligase $\mathrm{ml}^{-1}$ (Biolabs), and incubating at $14^{\circ} \mathrm{C}$ for $18 \mathrm{~h}$.

Transformation of E. coli cells with plasmid DNA. Recipient strains were made competent for transformation by the method of Dagert \& Ehrlich (1979). Transformations were carried out by mixing $3.75 \mu \mathrm{g}$ plasmid DNA with $50 \mu \mathrm{l}$ of the competent cells (at $1.2 \times 10^{10}$ cells $\mathrm{ml}^{-1}$ ), incubating first at $0^{\circ} \mathrm{C}$ for $10 \mathrm{~min}$ and then at $37^{\circ} \mathrm{C}$ for 5 min, diluting with $1 \mathrm{ml} \mathrm{LB}$, and incubating at $37^{\circ} \mathrm{C}$ for $1 \mathrm{~h}$. The transformed cells were selected on LB plates containing ampicillin $\left(100 \mu \mathrm{g} \mathrm{m} \mathrm{m}^{-1}\right)$. The plasmids were initially transformed into and checked for tetracycline

\section{Table 1. Organisms and plasmids used}

All genetic markers are as described by Bachmann \& Low (1980) except gsr and iex (Britton et al., 1982, 1983; Parra et al., 1983a). In the phage and plasmid designations cys ${ }^{+}$refers to OASL which may be the product of either the cys $K$ or cys $M$ gene though our evidence suggests it is the product of the cys $K$ gene.

\begin{tabular}{|c|c|c|c|}
\hline \multicolumn{2}{|c|}{ Organism/plasmid } & Genotype/phenotype & Origin \\
\hline E. coli & $\begin{array}{l}\text { C600 } \\
\text { DS410 } \\
\text { JM14 } \\
\text { JM559 } \\
\text { JM1705 } \\
\text { PB13 } \\
\text { PB15 } \\
\text { PB19 } \\
\text { PB20 } \\
\text { FP14 } \\
\text { FP45 } \\
\text { PO686 }\end{array}$ & 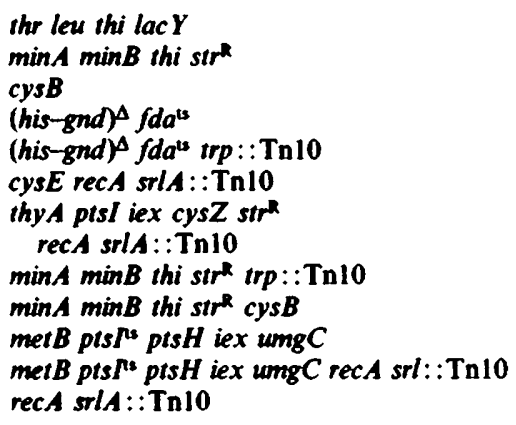 & $\begin{array}{l}\text { J. Reeve } \\
\text { Jones-Mortimer (1968) } \\
\text { Henderson et al. (1976) } \\
\text { JM559 and } \lambda \text { NK55 } \\
\text { Lee } \text { et al. }(1982) \\
\text { Britton et al. (1982) } \\
\text { P1.JM1705 } \rightarrow \text { DS410 } \\
\text { P1.JM14 } \rightarrow \text { PB19 } \\
\text { Britton et al. (1982, 1983) } \\
\text { P1.PO686 } \rightarrow \text { FP14 } \\
\text { P. Oliver }\end{array}$ \\
\hline$\lambda$ & $\begin{array}{l}\text { גJM29 } \\
\text { גNK55 }\end{array}$ & 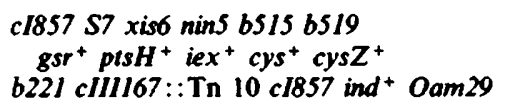 & $\begin{array}{l}\text { Britton et al. }(1982,1983) \\
\text { Kleckner et al. }(1978)\end{array}$ \\
\hline Plasmi & $\begin{array}{l}\text { pBR322 } \\
\text { pAB15 } \\
\text { pAB63 } \\
\text { pAB65 } \\
\text { pAB68 } \\
\text { pAB70 } \\
\text { pAB101 }\end{array}$ & 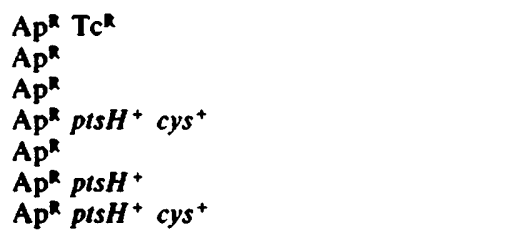 & $\begin{array}{l}\text { Bolivar et al. (1977) } \\
\text { Lee et al. (1982) } \\
\text { This paper } \\
\text { Lee et al. }(1982) \\
\text { This paper } \\
\text { This paper } \\
\text { This paper }\end{array}$ \\
\hline
\end{tabular}



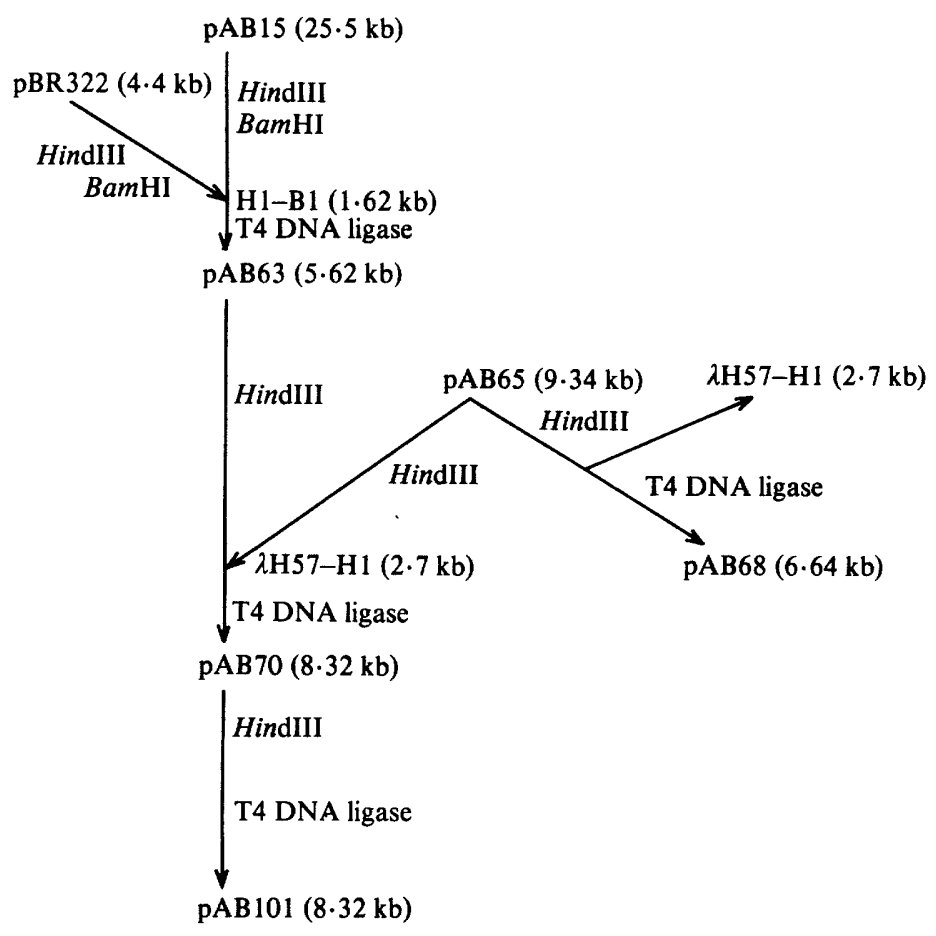

Fig. 1. Construction of the various recombinant plasmids [for construction of plasmids pAB15 and pAB65 see Lee et al. (1982)]. Plasmids pAB15, pAB65, pAB70 and pAB101 were all shown to be $p t s H^{+}$ by transformation of the ptsH strain FP45 to the PtsH ${ }^{+}$phenotype. Plasmid pAB65 did not carry the cys $\mathrm{Z}^{+}$gene as it did not transform the cys $Z$ strain $\mathrm{PB} 15$ to a cysteine prototroph. All the plasmids were phenotypically ampicillin-resistant but tetracycline-sensitive.

sensitivity in strain $\mathrm{C} 600$. The plasmids were then checked for their ability to complement the ptsH lesion in the recA strain FP45.

Preparation of plasmid-containing minicells. Minicells were prepared by a modification of the method described by Reeve (1979). The minicell-producing strains DS410 or PB20, containing the relevant plasmid, were grown overnight in $500 \mathrm{ml} \mathrm{LB}$ containing $10 \mathrm{mM}$-glucose, $64 \mu \mathrm{g} \mathrm{L}-$ methionine $\mathrm{ml}^{-1}, 2 \mu \mathrm{g}$ thiamin $\mathrm{ml}^{-1}$ and $100 \mu \mathrm{g}$ ampicillin $\mathrm{ml}^{-1}$. Cystine $\left(100 \mu \mathrm{g} \mathrm{ml}^{-1}\right)$ was included in the growth media for strain PB20. Modifying the method of Levy (1970), the cultures were centrifuged at $650 \mathrm{~g}$ for $10 \mathrm{~min}$ in a Sorvall RC 5B centrifuge to remove normal cells and the supernatant fractions were centrifuged again at $16000 \mathrm{~g}$ for $10 \mathrm{~min}$. The minicells were resuspended in $12 \mathrm{ml}$ sulphur-free Hershey salts (Worcel \& Burgi, 1974) and were purified twice through $10-30 \%(\mathrm{w} / \mathrm{v})$ sucrose gradients, containing sulphur-free Hershey salts prepared as described by Reeve (1979); these centrifugations were carried out in a $6 \times 38 \mathrm{ml}$ swing-out rotor in an MSE Superspeed 65 preparative ultracentrifuge at $5000 \mathrm{~g}$ for $7 \mathrm{~min}$. After the second sucrose gradient centrifugation, the minicells were spun at $20000 \mathrm{~g}$ for $10 \mathrm{~min}$ in a Sorvall RC 5B centrifuge and were resuspended in $4 \mathrm{ml}$ sulphur-free Hershey salts (about $10^{11}$ minicells $\mathrm{ml}^{-1}$ ). The minicell preparations were checked for contamination with normal-sized cells by phase-contrast microscopy: on average, less than one normal cell was found per $\sim 10^{8}$ minicells. The minicells were then centrifuged at $20000 \mathrm{~g}$ for $10 \mathrm{~min}$ and were resuspended in sulphur-free Hershey salts containing $30 \%(\mathrm{v} / \mathrm{v})$ glycerol, to approximately $2 \times 10^{10}$ minicells ml ${ }^{-1}$ (assuming an $A_{600}$ of 1 is equivalent to $10^{10}$ minicells ml ${ }^{-1}$ ) and stored at $-80^{\circ} \mathrm{C}$.

Expression of plasmid-encoded proteins in minicells. Samples $(100 \mu l)$ of purified minicells $\left(2 \times 10^{10}\right.$ minicells $\mathrm{ml}^{-1}$ ) were centrifuged in a 5412 Eppendorf microfuge for $7 \mathrm{~min}$ at room temperature and were resuspended in $100 \mu \mathrm{l}$ sulphur-free Hershey salts containing $20 \mathrm{mM}$-glucose, $2 \mathrm{mM}-\mathrm{cAMP}, 100 \mu \mathrm{g}$ ampicillin $\mathrm{ml}^{-1}$ and $50 \mu \mathrm{g}$ of $\mathrm{D}$ cycloserine $\mathrm{ml}^{-1}$ [to destroy any contaminating viable cells (Reeve, 1979)]. The samples were incubated at $37^{\circ} \mathrm{C}$ for $1 \mathrm{~h}$ to destroy any endogenous mRNA. Labelling of the plasmid-encoded proteins was carried out by adding $\mathrm{L}$ ${ }^{35}$ S]methionine (final concentration $200 \mu \mathrm{Ci} \mathrm{ml}^{-1} ; 7.4 \mathrm{MBq} \mathrm{ml}^{-1}$ ) or [U-14 $\left.\mathrm{C}\right]$ protein hydrolysate (final concentration $10 \mu \mathrm{Ci} \mathrm{ml}^{-1} ; 0.37 \mathrm{MBq} \mathrm{ml}^{-1}$ ) and incubating for $1 \mathrm{~h}$ at $37^{\circ} \mathrm{C}$. The incorporation of isotope was stopped by adding either L-methionine, to a final concentration of $800 \mu \mathrm{g} \mathrm{ml}^{-1}$ when ${ }^{35} \mathrm{~S}$ was the isotope used, or $10 \mu 11 \%$ casein hydrolysate when ${ }^{14} \mathrm{C}$-labelled amino acids were used, and incubating for $10 \mathrm{~min}$ at $37^{\circ} \mathrm{C}$. The 
minicells were then centrifuged for $7 \mathrm{~min}$ in a 5412 Eppendorf microfuge and resuspended in $20 \mu \mathrm{LDS}$ disecciating buffer and analysed by SDS-PAGE using 12-20\% gradient gels (Britton $e t$ al., 1982). ${ }^{35}$ S-Labelled polypeptides were identified by fluorography as described by Britton et al. (1982). The ${ }^{14} \mathrm{C}$-labelled amino acidcontaining polypeptides were exposed for $5 \mathrm{~d}$ at $-80^{\circ} \mathrm{C}$ in contact with the $\mathrm{X}$-ray film. The sizes of the polypeptides were calculated using the following marker proteins: BSA (68500), bovine $\gamma$-globulin (50000 and 23500), ovalbumin (43000), myoglobin (18500) and lysozyme (14300).

Fractionation of minicells. After labelling with isotopes, the minicells were centrifuged for $7 \mathrm{~min}$ in a 5412 Eppendorf microfuge and were resuspended in $40 \mu \mathrm{l} 0.2 \mathrm{M}$-Tris/HCl, $\mathrm{pH} \mathrm{8.0.} \mathrm{Spheroplasts} \mathrm{were} \mathrm{prepared} \mathrm{by} \mathrm{a}$ slight modification of the method described by Witholt et al. (1976a). To the minicell suspensions was added $0.2 \mathrm{M}-$ Tris/ $/ \mathrm{Cl}$, pH 8.0, containing $1 \mathrm{M}$-sucrose and $1 \mathrm{mw-K} \mathrm{K}_{2}$ EDTA, pH 8.0 (40 $\left.\mu \mathrm{l}\right)$ followed 2 min later by $20 \mu \mathrm{l}$ lysozyme $\left(1 \mathrm{mg} \mathrm{ml}^{-1}\right)$ in the sucrose buffer. After incubation at room temperature for $2 \mathrm{~min}$, the minicells were exposed to a mild osmotic shock by the addition of $100 \mu$ l deionized water to trigger lysozyme penetration of the outer membrane (Witholt et al., 1976b). The minicells were then incubated at room temperature for $1 \mathrm{~h}$. The spheroplasts were centrifuged as above and were burst by resuspending them in $20 \mu \mathrm{l}$ water. After centrifugation for $15 \mathrm{~min}$, the supernatant solutions containing the cytoplasmic proteins were removed. The membranes were washed twice in $100 \mu \mathrm{l}$ water and were finally resuspended in $20 \mu \mathrm{l}$ water. Both the cytoplasmic and membrane fractions were analysed by SDS-PAGE after the addition of $20 \mu$ SDS-dissociating buffer; staining the gels with Comassie blue showed reproducible differences in the protein profiles.

Assay of $O$-acetylserine (thiol)-lyase. Strains were grown in minimal media supplemented with 10 mM-sodium lactate and ampicillin $\left(100 \mu \mathrm{g} \mathrm{ml}{ }^{-1}\right)$ with or without cystine $\left(100 \mu \mathrm{g} \mathrm{ml}{ }^{-1}\right)$ at $37^{\circ} \mathrm{C}$ overnight. Samples $(20 \mathrm{mg} \mathrm{dry}$ mass $\mathrm{ml}^{-1}$ ) were sonicated in an ultrasonic bath (Megason) for $10 \mathrm{~min}$, centrifuged and the supernatants assayed for the production of cysteine from $O$-acetylserine and hydrogen sulphide according to the method of Fimmel \& Loughlin (1977).

Purification of O-acetylserine (thiol)-lyase. A crude extract from strain PB13(pAB65) was prepared as described by Lee et al. (1982), except all buffers contained $0 \cdot 1$ mu-phenylmethylsulphonyl fluoride and 1 mu-benzamidine. OASL was initially purified by ion-exchange chromatography on a Whatman DE-52 DEAE-cellulose column (2.5 $\times 7 \mathrm{~cm}$ ) previously equilibrated with $0.01 \mathrm{M}-\mathrm{Tris} / \mathrm{HCl}, \mathrm{pH} 7.6$. A $400 \mathrm{ml}$ linear concentration gradient $(0-0.2 \mathrm{M}-$ $\mathrm{NaCl}$ in $0.01 \mathrm{~m}-\mathrm{Tris} / \mathrm{HCl}, \mathrm{pH} 7.6$ ) was used to elute OASL. Fractions (4 ml) were rollected and analysed by SDSPAGE on 12-20\% gradient gels; those containing a large excess of a polypeptiue of $M_{\mathrm{r}} 34000$ were pooled and dialysed against $0.01 \mathrm{M}$-potassium phosphate buffer, pH 7.6. The dialysed material was then applied to a hydroxyapatite column $(1 \times 6 \mathrm{~cm})$ previously equilibrated with $0.01 \mathrm{k}$-potassium phosphate buffer, $\mathrm{pH} 7.6$, and was eluted directly onto a second Whatman DE-52 DEAE-cellulose column $(1 \times 6 \mathrm{~cm})$. OASL was eluted with $0.15 \mathrm{M}-\mathrm{NaCl}$ in $0.01 \mathrm{M}-\mathrm{Tris} / \mathrm{HCl}, \mathrm{pH} \mathrm{7.6}$, and further purified by gel permeation chromatography on an LKB Ultrogel AcA 44 column $(1.5 \times 55 \mathrm{~cm})$ equilibrated with $0.1 \mathrm{M}-\mathrm{Tris} / \mathrm{HCl}, \mathrm{pH} 7 \cdot 6$. Fractions showing a single polypeptide of $M_{r} 34000$ were pooled and assayed for OASL activity.

Ultracentrifugation analysis. Ultracentrifugation was carried out in a Spinco Model E analytical ultracentrifuge. Sedimentation velocities were determined at 59780 r.p.m. in a single sector cell or 52640 r.p.m. in a double sector cell using Schlieren optics with continuous temperature measurement. All samples were centrifuged after exhaustive dialysis in $0.1 \mathrm{M}$ sodium and potassium phosphate buffer containing $0.05 \mathrm{M}-\mathrm{NaCl}$ at $\mathrm{pH} 7.5$ (ionic strength $=0 \cdot 1)$. The partial specific volume (D) of OASL was determined from the amino acid analysis as described by Lee \& Timasheff (1974).

Amino acid analysis. Amino acid analyses were performed on an LKB model $\mathbf{4 4 0 0}$ amino acid analyser Samples $\left(0.5 \mathrm{mg} \mathrm{ml}{ }^{-1}\right.$ ) were exhaustively dialysed against $10 \mathrm{~mm}-\mathrm{NH}_{4} \mathrm{HCO}_{3}$ and freeze-dried. Samples were hydrolysed as described by Lee et al. (1982). A sample was initially oxidized with performic acid and then hydrolysed in order to determine cysteine as cysteic acid (Perham, 1978).

\section{RESULTS}

\section{Expression of the recombinant plasmids}

Two polypeptides, of $M_{\mathrm{r}} 28000$ and 26000 , were expressed from all recombinant plasmids. These are the product of the ampicillin resistance gene, bla, present on pBR322 DNA (Sutcliffe, 1978). The polypeptide of $M_{\mathrm{r}} 26000$ is the processed and active form of the bla gene product $\left(M_{\mathrm{r}}\right.$ 28000) (Ambler \& Scott, 1978).

Plasmid pAB65 expressed three polypeptides, of $M_{\mathrm{r}} 9000,33000$ and 49000 ; these were also expressed by the specialized transducing phage $\lambda \mathrm{JM} 29$ (Britton et al., 1982) from which pAB65 was derived (Lee et al., 1982). The polypeptides of $M_{\mathrm{r}} 49000$ and 9000 are known to be the products of part of the ptsI, and of the ptsH genes, respectively (Britton et al., 1982; Lee et al., 1982). However, we suspected that the polypeptide of $M_{\mathrm{r}} 33000$ might be a doublet. To improve the 


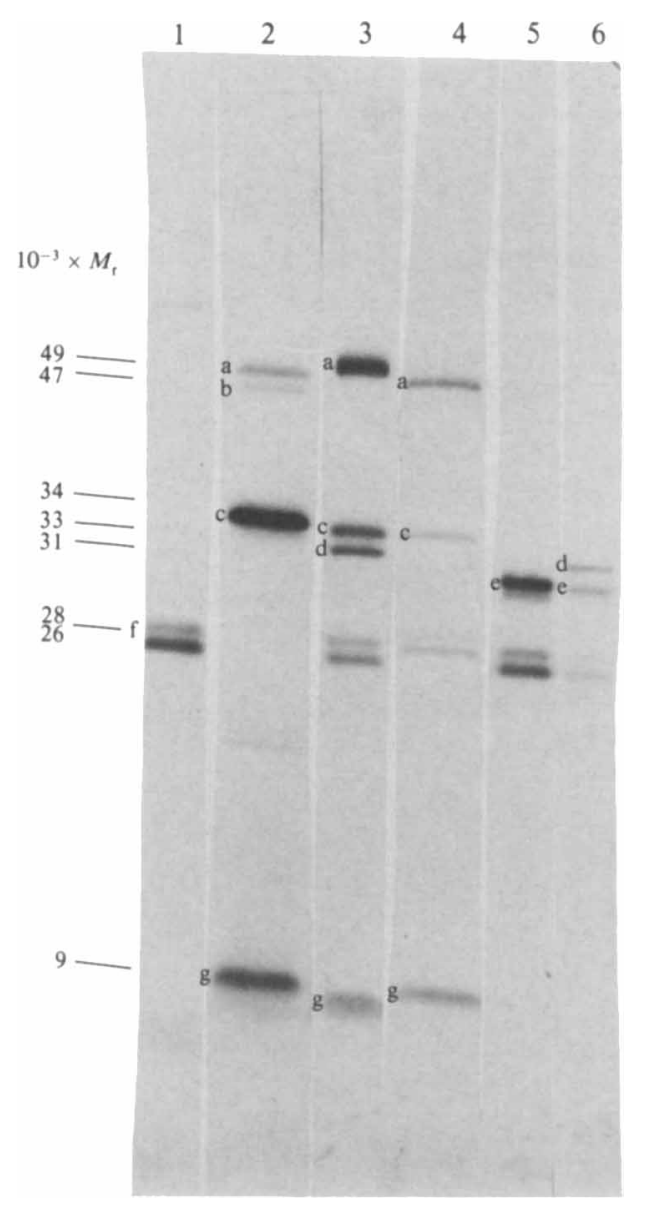

Fig. 2. Fluorogram of the $\left[{ }^{35} S\right]$ methionine-labelled polypeptides expressed from the recombinant plasmids in minicells. Track 1 , the ampicillin-resistant gene products, modified and unmodified, derived from plasmid pBR322; track 2, expression pattern from $\lambda J M 29$ as described by Britton et al. (1982); track 3, expression pattern of plasmid pAB65; track 4, expression pattern of plasmid pAB101; track 5 , expression pattern of plasmid pAB63; track 6, expression pattern of plasmid pAB68. The gels were $12-20 \%$ gradients, electrophoresed at $4{ }^{\circ} \mathrm{C}$. a, Enzyme I fragment; b, bEa59 fragment; c, OASL; $\mathrm{d}$, bEa59 fragment; e, OASL fragment; $\mathrm{f}, \boldsymbol{\beta}$-lactamase; $\mathrm{g}$, HPr (histidine-containing protein of the phosphotransferase system).

resolution of the SDS-PAGE, the analysis of the polypeptides expressed by plasmid pAB65 was carried out at $4{ }^{\circ} \mathrm{C}$; under these conditions, not only a polypeptide of $M_{\mathrm{r}} 33000$ but also another of $M_{\mathrm{r}} 34000$ was observed (Fig. 2, track 3). The polypeptide pattern obtained after labelling with $\left[{ }^{14} \mathrm{C}\right]$ amino acids appeared to be identical to that obtained after labelling with $\left[{ }^{35}\right.$ S $]$ methionine. Analysis of the polypeptides expressed by the specialized transducing phages at $4{ }^{\circ} \mathrm{C}$ also showed that several expressed a polypeptide of $M_{\mathrm{r}} 34000$, which co-electrophoresed with a polypeptide expressed from plasmid pAB65, but no polypeptide of $M_{\mathrm{r}} 33000$ was expressed from any phage (Fig. 2, track 2 for the expression of $\lambda \mathrm{JM} 29$ ).

We suspected that the polypeptide of $M_{\mathrm{r}} 34000$ might be a subunit of OASL since the cys $K$ gene is known to map at about $52 \mathrm{~min}$ on the $E$. coli chromosome (Fimmel \& Loughlin, 1977). The $c y s B$ minicell-producing strain PB20 was constructed by transduction to determine the effect on the expression of the polypeptide of $M_{\mathrm{r}} 34000$ in the absence of the positive regulator of the cysteine biosynthetic enzymes. Plasmid pAB65 was expressed in minicells derived from strain DS410 in the presence and absence of cystine $\left(120 \mu \mathrm{g} \mathrm{ml}^{-1}\right)$ and any polypeptides 


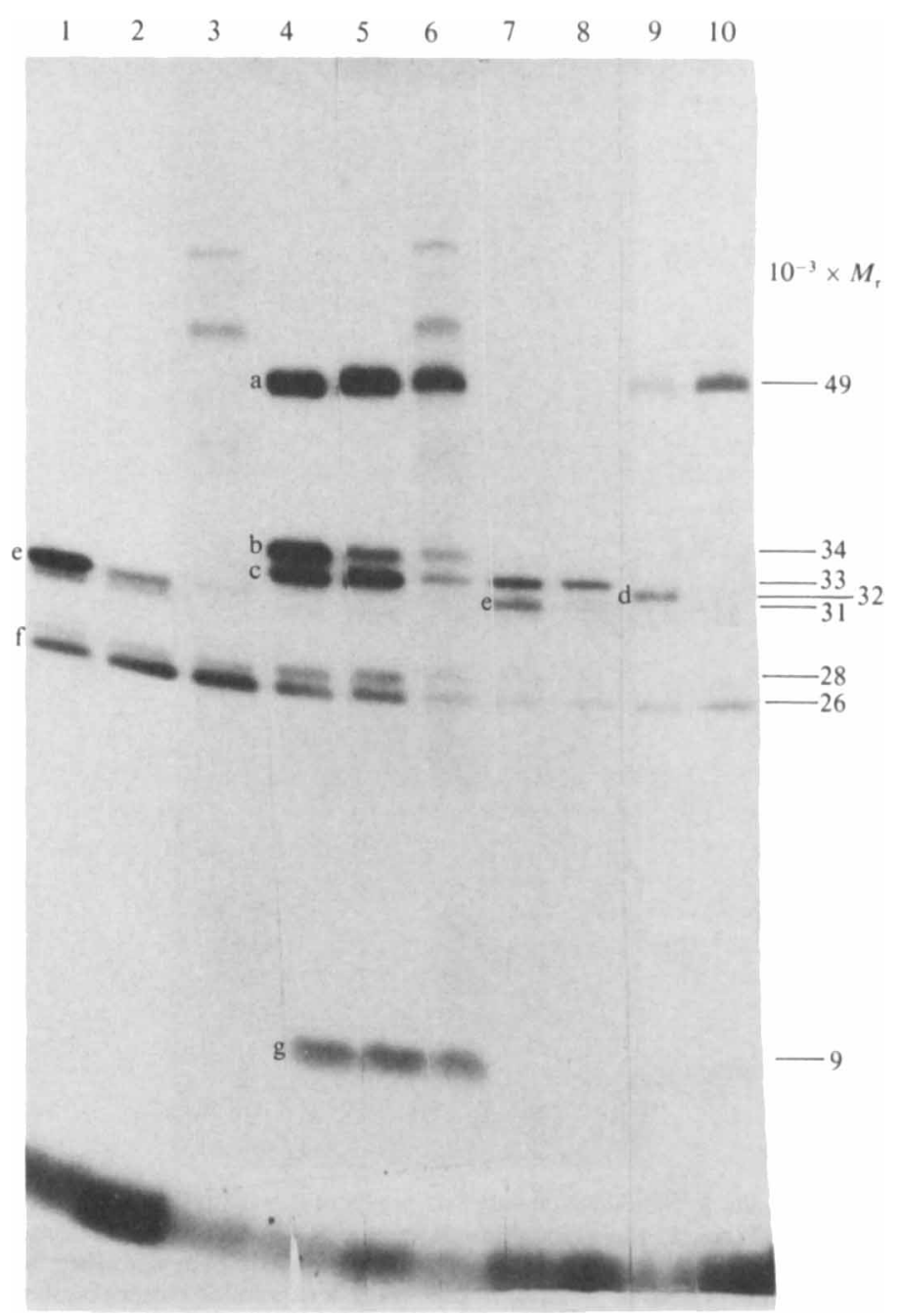

Fig. 3. Fluorogram of the [35S]methionine-labelled polypeptides expressed in the presence or absence of cystine in the cys $B^{+}$strain DS410 or in the cysB strain PB20 minicells. Track 1, DS410(pAB63) minicells, no cystine; track 2, DS410(pAB63) minicells plus cystine; track 3, PB20(pAB63) minicells; track 4, DS410(pAB65) minicells, no cystine; track 5, DS410(pAB65) minicells plus cystine; track 6, PB20(pAB65) minicells; track 7, DS410(pAB68) minicells, no cystine; track 8, DS410(pAB68) minicells plus cystine; track 9, DS410(pAB70) minicells, no cystine; track 10, DS410(pAB70) minicells plus cystine. a, Enzyme I fragment; b, OASL; c, bEa59 fragment; d, OASL fragment; e, OASL fragment; f, $\beta$-lactamase; $g$, HPr (histidine-containing protein of the phosphotransferase system).

expressed were labelled with $\left[{ }^{14} \mathrm{C}\right]$ amino acids. The plasmid was also expressed in strain PB20 previously grown in the presence of cystine and then sulphur-starved. Polypeptides were again labelled with [ ${ }^{14} \mathrm{C}$ ]amino acids. The expression of the polypeptide of $M_{\mathrm{f}} 34000$ was depressed both in the presence of cystine in the cysB $B^{+}$strain DS410 and in the cysB strain PB20 in the absence of cystine (Fig. 3, tracks 4, 5 and 6). The expression of the polypeptide of $M_{\mathrm{r}} 33000$ was depressed only in the cysB strain PB20.

To identify the location of the genes expressing the polypeptides of $M_{\mathrm{r}} 34000$ and 33000 , several plasmids were derived from plasmid pAB65 (Fig. 1). Plasmid pAB63 expressed a polypeptide of $M_{\mathrm{r}} 30800$ (Fig. 2, track 5) which was also repressed in the presence of cystine in minicells derived from the cysB $B^{+}$strain DS410 and in minicells derived from the cysB strain 
Table 2. Plasmid-specified O-acetylserine (thiol)-lyase activity

\begin{abstract}
Activity was measured as described by Fimmel \& Loughlin (1977). Five determinations were carried out on each extract, using different amounts of extract; activity is expressed relative to that of strain DS410(pBR322) grown in the absence of cystine. This latter formed 27 pmol cysteine (mg dry mass cell extract) ${ }^{-1} \min ^{-1}$.
\end{abstract}

\begin{tabular}{|c|c|c|c|c|}
\hline \multirow[b]{3}{*}{ Plasmid } & \multirow{3}{*}{$\begin{array}{r}\text { Host } \ldots \\
\text { Cystine in medium }\end{array}$} & \multicolumn{3}{|c|}{ Relative OASL activity } \\
\hline & & DS410 (cysB $\left.B^{+}\right)$ & DS410 $\left(\operatorname{cys} B^{+}\right)$ & PB20 (cysB) \\
\hline & & $\ldots \quad-$ & + & - \\
\hline pBR322 & & 100 & 4 & ND \\
\hline pAB63 & & 100 & 4 & 7 \\
\hline pAB65 & & 433 & 233 & 30 \\
\hline pAB68 & & 215 & 4 & ND \\
\hline pAB70 & & 144 & 15 & ND \\
\hline pAB101 & & 741 & 348 & 130 \\
\hline
\end{tabular}

PB20 (Fig. 3, tracks 1, 2 and 3). This suggested that the initiation site for one of the polypeptides lay within the H1-B1 region of the cloned DNA (Fig. 5) and that its promoter was under the regulation of cysteine and the cysB gene product.

Plasmid pAB68 expressed two polypeptides of $M_{\mathrm{r}} 30800$ and 33000 (Fig. 2, track 6). The polypeptide of $M_{\mathrm{r}} 30800$ was repressed by cystine in the minicell system but the expression of the polypeptide of $M_{\mathrm{r}} 33000$ was not depressed in the presence of cystine (Fig. 3, tracks 7 and 8). The difference between plasmids pAB63 and pAB68 was that plasmid pAB68 contained a piece of $\lambda$ DNA, fragment $\lambda \mathrm{E} 54.3-\lambda \mathrm{H} 57$ (Fig. 5). This raised the possibility that the polypeptide of $M_{\mathrm{r}}$ 33000 might be expressed from $\lambda$ DNA and that the polypeptide of $M_{\mathrm{r}} 30800$ was a fragment of the polypeptide of $M_{\mathrm{r}} 34000$. To answer this problem two more derivatives of plasmid pAB65 were constructed, plasmids pAB70 and pAB101 (Figs 1 and 5).

Plasmid pAB70 expressed three polypeptides of $M_{\mathrm{r}} 49000,32000$ and 9000 (Fig. 3, track 9) confirming that the polypeptides of $M_{\mathrm{r}} 49000$ and 9000 originated from the H57-H1 DNA fragment as observed by Britton et al. (1983). The polypeptide of $M_{\mathrm{r}} 32000$ must originate from the H1-B1 DNA fragment as a polypeptide of $M_{\mathrm{r}} 30800$, showing the same regulatory properties, was expressed from plasmids pAB63 and pAB68. The polypeptide of $M_{\mathrm{r}} 32000$ was repressed in the presence of cystine (Fig. 3, tracks 9 and 10). The increase in the size of the polypeptide fragment $\left(M_{\mathrm{r}} 32000\right.$ as opposed to 30800$)$ is probably due to a different stop codon or transcriptional termination site resulting from the $\mathrm{H} 1-\mathrm{B} 1$ fragment being joined to a small piece of $\lambda$ DNA in pAB70 rather than to pBR322 DNA as in pAB65. The differences between plasmids pAB70 and pAB65 were that the $\lambda E 54.3-\lambda H 57$ DNA fragment was absent and that the $\lambda$ H57-H1 DNA fragment was orientated in the opposite direction (Fig. 5). The $\lambda \mathrm{H} 57-\mathrm{H} 1 \mathrm{DNA}$ fragment of pAB70 was re-orientated to give plasmid $\mathrm{pAB} 101$, which thus differed from plasmid pAB65 only by the absence of the $\lambda E 54.3-\lambda$ H57 DNA fragment. Plasmid pAB101 expressed three polypeptides of $M_{\mathrm{r}} 49000,34000$ and 9000 (Fig. 2, track 4); the polypeptide of $M_{\mathrm{r}} 34000$ was repressed in the presence of cystine (data not shown). A polypeptide of $M_{\mathrm{r}} 34000$ was specified by pAB101 and a polypeptide of $M_{\mathrm{r}} 32000$ by pAB70. This would only be possible if the polypeptides of $M_{\mathrm{r}} 30800$ and 32000 were fragments of the polypeptide of $M_{\mathrm{r}} 34000$. The transcription of these polypeptides therefore originated in the H1-B1 DNA fragment and ran into the K2-H1 DNA fragment (Fig. 5).

\title{
Determination of $\mathrm{O}$-acetylserine (thiol)-lyase activity
}

The activity of OASL in plasmid-bearing strains was investigated under different conditions: $(a)$ in the absence of cystine, $(b)$ in the presence of cystine and $(c)$ in the cysB strain PB20 (Table 2). Only two plasmids, pAB65 and pAB101, caused the expression of OASL activities higher than normal; in the absence of cystine there was a 4.3-fold increase in the case of pAB65 and a 7-4-fold increase in the case of pAB101 compared to basal levels in the absence of cystine. The 
Table 3. Amino acid composition of $O$-acetylserine (thiol)-lyase

\begin{tabular}{lcc} 
& \multicolumn{2}{c}{$\begin{array}{c}\text { Composition [mol residue (mol subunit) }{ }^{-1} \text { ] } \\
\text { according to: }\end{array}$} \\
\cline { 2 - 3 } Amino acid & This paper & Becker et al. (1969) \\
Asp & 24.7 & 25.5 \\
Thr* & 21.0 & 24.0 \\
Ser* & 22.1 & 17.0 \\
Glu & 37.1 & 37.5 \\
Pro & 15.2 & 15.8 \\
Gly & 35.4 & 32.6 \\
Ala & 30.1 & 30.8 \\
Cyst & 0.0 & 0.7 \\
Val & 18.8 & 19.2 \\
Met & 4.4 & 4.9 \\
Ile & 24.5 & 24.1 \\
Leu & 31.3 & 31.6 \\
Tyr & 5.6 & 6.4 \\
Phe & 14.4 & 7.2 \\
His & 3.1 & 3.0 \\
Lys & 22.9 & 25.5 \\
Arg & 12.7 & 13.4 \\
Trp & ND & 5.0
\end{tabular}

ND, not determined.

- Determined from means of $24 \mathrm{~h}, 48 \mathrm{~h}$ and $72 \mathrm{~h}$ hydrolysis times.

$\uparrow$ Determined as cysteic acid after performic acid oxidation.

$\$$ Determined after extrapolation to zero time.

activities of OASL in strains transformed with these plasmids, was still regulated by cystine and to a lesser extent the cysB $B^{+}$product (Table 2 ). These findings confirmed that plasmids pAB65 and $\mathrm{PAB} 101$ carried a gene for OASL. The incomplete repression of OASL by cystine in strains carrying the plasmids is not in accord with the simplest forms of the positive control model. Though it may be necessary to elaborate the model, the possibility exists that the residual expression is from another $E$. coli promoter in the H1-B1 DNA fragment.

The observation that plasmids pAB65 and pAB101 increased the production of OASL also confirmed that the polypeptide of $M_{\mathrm{r}} \mathbf{3 4 0 0 0}$ must be the product of a structural gene for OASL. The polypeptide of $M_{\mathrm{r}} 33000$ did not have any role in the activity of OASL, as shown by comparison of plasmid pAB68, which expressed the polypeptide of $M_{\mathrm{r}} 33000$ but had no OASL activity, with plasmids $\mathrm{pAB} 65$ and $\mathrm{pAB} 101$.

\section{Properties of $O$-acetylserine (thiol)-lyase}

The OASL isolated had an intense yellow colour indicative of the pyridoxal phosphate prosthetic group and the absorption spectrum was identical with that described by Becker $e t$ al. (1969).

Amino acid composition. The amino acid composition (Table 3) was found to be very similar to that obtained by Becker et al. (1969) for the OASS-A produced by the $S$. typhimurium cysK gene.

Molecular weight. Three different concentrations of purified OASL were used $[0.5 \%, 0.25 \%$ and $0.125 \%(w / v)]$ in order to calculate a $520, w$ value. In each case a single and symmetrical sedimenting boundary was observed. The sedimentation velocities were calculated and corrected to their $s_{20, w}$ values. They were then extrapolated to zero protein concentration yielding a value for $s_{20, w}$ of $4.7 \mathrm{~S}$. This indicated that the native protein had an $M_{\mathrm{r}}$ of about 65000 . A protein of $M_{\mathrm{r}} 34000$ would be expected to have a sedimentation velocity of about $2.5 \mathrm{~S}$.

The molecular weight of the active OASL molecule was calculated using the equation (Schachman, 1959):

$$
M=N . f . s_{20, w} \cdot \frac{1}{(1-\bar{v} \rho)}
$$




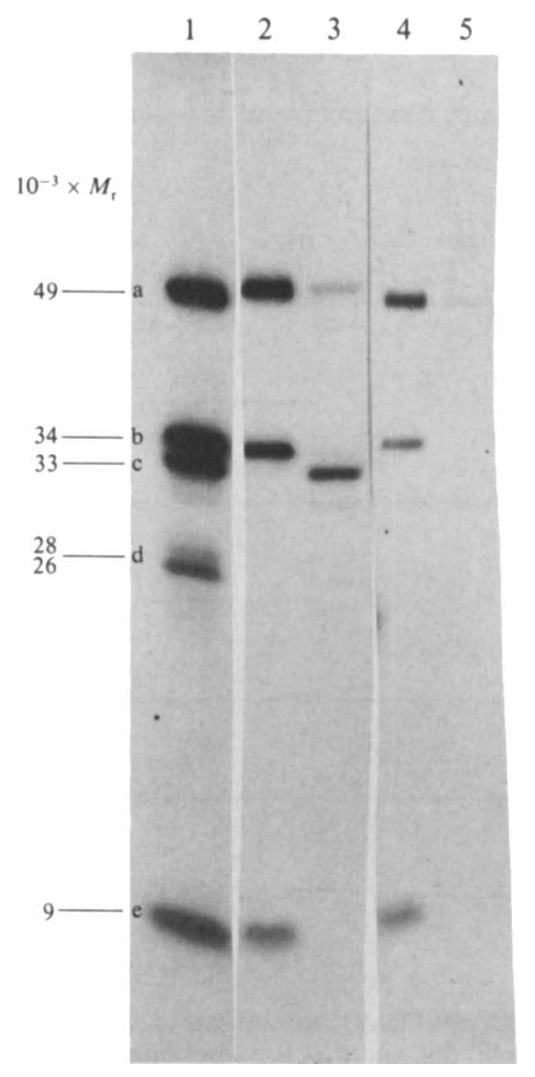

Fig. 4. Fluorogram of the $\left.{ }^{35} S\right]$ methionine-labelled polypeptides expressed from the recombinant plasmids pAB65 and pAB101 following fractionation into cytoplasmic and membrane components of the minicells. Track 1, expression pattern of plasmid pAB65 without fractionation; track 2, cytoplasmic polypeptides from pAB65; track 3, membrane-associated polypeptides from pAB65; track 4, cytoplasmic polypeptides from pAB101; track 5 , membrane-associated polypeptides from pAB101. a, Enzyme I fragment; b, OASL; c, bEa59 fragment; $d, \beta$-lactamase; $e, H P r$ (histidine-containing protein of the phosphotransferase system).

where the $\bar{v}$ was calculated as 0.744 from the amino acid composition. The frictional coefficient $(f)$ was calculated assuming an $f / f_{0}$ ratio of $1 \cdot 15$, the ratio obtained for haemoglobin $\left(M_{\mathrm{r}} 68500\right)$ (Alexander \& Johnson, 1949). The molecular weight of OASL was found to be 64000 indicating that it was a dimer of the polypeptide $\left(M_{\mathrm{r}} 34000\right)$ expressed from the cloned $E$. coli DNA.

\section{Identity of the polypeptide of $M_{r} 33000$}

Several of the plasmids were expressed in DS410-derived minicells. The resulting proteins were labelled with $\left[{ }^{35}\right.$ S $]$ methionine, fractionated into cytoplasmic- and membrane-associated proteins and analysed by SDS-PAGE. The processed and unprocessed products of the bla gene were lost in the fractionation process indicating that they were present in the periplasmic fraction as observed by Ambler \& Scott (1978). The polypeptides of $M_{\mathrm{r}} 49000,34000$ and 9000 were all found to be associated with the cytoplasm (Fig. 4, tracks 2 and 4). The polypeptide of $M_{\mathrm{r}}$ 33000 was found to be entirely membrane-associated (Fig. 4, track 3).

The difference between plasmids pAB63 and pAB68, and plasmids pAB65 and pAB101, was that plasmids pAB65 and pAB68 contained a piece of $\lambda$ DNA stretching from the $\lambda E 54.3$ site to the $\lambda H 57$ site (Fig. 5). The plasmids carrying $\lambda$ DNA also expressed a polypeptide of $M_{\mathrm{r}} 33000$ that had no OASL activity, as observed from plasmid pAB68, and which was membrane- 


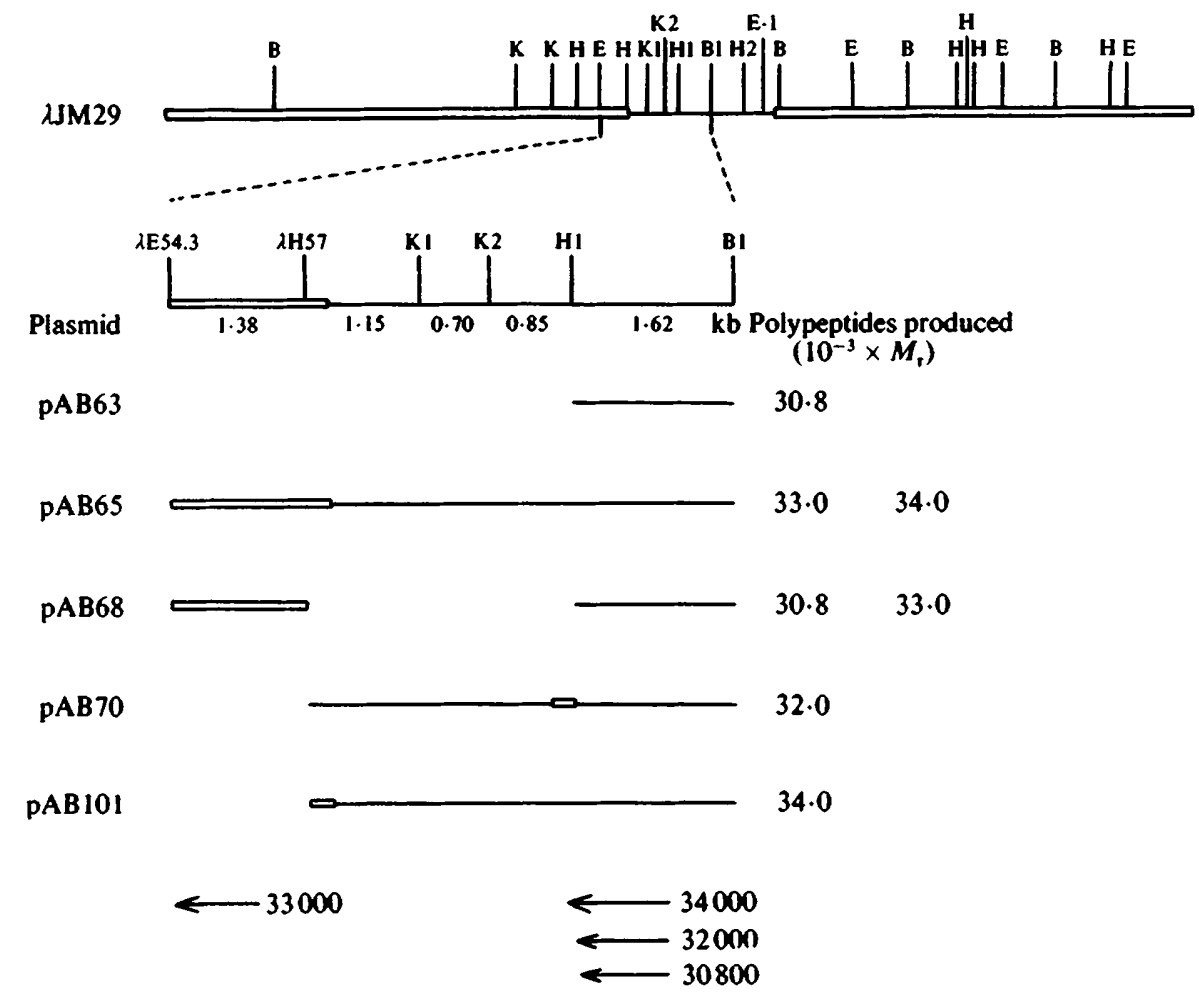

Fig. 5. Maps of $\lambda$ JM29 and of E. coliDNA in recombinant plasmids derived from it. The DNA derived from $E$. coli is shown as a solid line and that from bacteriophage $\lambda$ as an open box. The $\lambda H 57-H 1$ fragment in plasmid pAB70 is inverted as compared to its original orientation in plasmid pAB65. Only the relevant polypeptides expressed by the plasmids are included. The arrows show the position and direction of expression of the polypeptides of $M_{s} 30800,32000,33000$ and 34000 . The position of the $\lambda$ ben gene is derived from the position of bEa59 on the $\lambda$ DNA map (Sanger et al., 1982). The position of the gene producing OASL is deduced from the recombinant plasmids. For the construction of the plasmids see Fig. 1 .

associated rather than cytoplasmic. The removal of the $\lambda$ DNA from plasmid pAB65 (resulting in plasmid pAB101) caused the loss of the polypeptide of $M_{r} 33000$, confirming that it was specified by $\lambda$ DNA. Examination of the $\lambda$ DNA sequence reported by Sanger et al. (1982) from $\lambda E 54.3$ to the $\lambda$ attachment site, shows that it encodes part of the $\lambda$ protein bEa59 (Epp, 1978), the product of the $\lambda$ ben gene (Sumner-Smith et al., 1982). Calculation of the relative molecular mass of the bEa59 fragment, from the amino acid sequence derived from the known DNA sequence, indicated that it should have an $M_{\mathrm{r}}$ of 33000 . The sequence of the resulting polypeptide showed a high percentage ( $57 \%$ ) of hydrophobic amino acids which occur in long consecutive stretches. This might cause hydrophobic domains and thus account for binding to the membrane.

The labelling of polypeptides expressed from the specialized $\lambda$ transducing phages (Britton $e t$ $a l ., 1982)$ showed that two of the phages, $\lambda J M 29$ and $\lambda J M 133$, expressed a polypeptide of $M_{\mathrm{r}}$ 47000 (Fig. 2, track 2) originally thought to be the product of the E. coli xap gene (Britton $e$ al., 1982). Sumner-Smith et al. (1982), showed that the DNA encoding the bEa59 protein, the $\lambda$ ben gene, contains part of the b515 deletion. Using the $\lambda$ map of Szybalski \& Szybalski (1979) we calculated that the $b 515$ deletion in the $\lambda$ ben gene would result in a bEa59 fragment of about $M_{\mathrm{r}}$ 45000 , the loss being at the $C$-terminal end of the protein. This suggested that the polypeptide of $M_{\mathrm{r}} \mathbf{4 7 0 0 0}$ expressed from the two phages is the product of the partially deleted $\lambda$ ben gene. It is known (Sumner-Smith et al., 1982) and further confirmed by the $\lambda$ DNA sequence data of F. 
Sanger (unpublished) that the $\lambda$ ben gene is expressed from the $\lambda P_{L}$ promoter. The evidence from plasmids pAB65 and pAB68 indicated that the partially deleted $\lambda$ ben gene could also be expressed from an $E$. coli promoter of the cysteine regulon, since repression of this promoter by the absence of the $c y s B$ gene product resulted in a decrease in the amount of the polypeptide of $M_{\mathrm{r}} 33000$ being produced. It is probable that the polypeptide of $M_{\mathrm{r}} \mathbf{4 7 0 0 0}$ expressed by the specialized $\lambda$ transducing phages $\lambda \mathrm{JM} 29$ and $\lambda \mathrm{JM} 133$ is also expressed from the same $E$. coli promoter, as, in the protein labelling experiments of Britton et al. (1982), the $\lambda P_{L}$ promoter is completely shut off.

\section{DISCUSSION}

Our results show that the DNA subcloned from $\lambda J M 29$, the $\lambda E 54.3-B 1$ fragment, encodes a gene for $O$-acetylserine (thiol)-lyase. The product of this gene, a polypeptide of $M_{\mathrm{r}} 34000$, is controlled by the level of cysteine and a positive regulator, the $c y s B$ gene product. It was initially thought that the active OASL molecule may consist of two polypeptide subunits of $M_{\mathrm{r}} 34000$ and 33000. Subsequent investigations showed that the polypeptide of $M_{\mathrm{r}} 33000$ was expressed from $\lambda$ DNA. The active OASL molecule specified by the plasmid exists as a dimer of the polypeptide of $M_{\mathrm{r}} 34000$, from the analytical ultracentrifugation data, as was the case for $S$. typhimurium (Becker et al., 1969). The $O$-acetylserine sulphydrylase A isoenzyme of $S$. typhimurium is specified by the cysK gene (Becker et al., 1969). We have purified the OASL specified by a plasmid carrying chromosomal DNA from $E$. coli and determined its amino acid composition. The similarity of the composition of this protein to that given by Becker et al. (1969) for the A isoenzyme of OASL suggests to us that our plasmid-encoded enzyme is homologous with the A isoenzyme of $S$. typhimurium and thus that the cloned gene is homologous with cysK. If so, the cys $K$ gene in E. coli lies between the KpnI and BamHI sites, labelled K2 and B1 on our map (Fig. $5)$ and the gene contains a HindIII site (H1). The properties of the polypeptide of $M_{\mathrm{r}} 30800$ expressed from plasmids pAB63 and pAB68 show that the initiation site for the cysK structural gene is about $1 \mathrm{~kb}, 90 \%$ of the gene, to the left of the $\mathrm{H} 1$ site and that the $\mathrm{C}$-terminus of the gene lies about $0 \cdot 1 \mathrm{~kb}$ to the right of the $\mathrm{H} 1$ site (Fig. 5). The cysK promoter must also lie between the $\mathrm{H} 1$ and $\mathrm{B} 1$ sites. The observation that a $\lambda$ gene, about $3.5 \mathrm{~kb}$ downstream, is expressed from the cys $K$ promoter suggests that the promoter is very efficient and that there are no efficient transcription termination sites on the $E$. coli DNA cloned. The termination site for the mRNA transcript from the cys $K$ promoter must lie in the plasmid DNA. If a rho $(\rho)$ dependent termination site exists after cys $K$ the level of $\rho$ must be decreased in the minicells. There was no evidence that either the ptsH or ptsI genes were under the regulation of cysteine or the cysB product indicating they have their own promoters.

Results from this paper and from the work of Britton et al. $(1982,1983)$ show that the order of genes at about $52 \mathrm{~min}$ in the $E$. coli chromosome is:

\section{2' cysA gsr ptsI ptsH cysK cysZ lig dsd 51'}

The iex mutation described by Parra et al. $(1983 a)$ and Britton et al. $(1982,1983)$ may lie between the ptsI and ptsH or ptsH and cysK genes. In contrast, the gene order in $S$. typhimurium (Sanderson \& Hartman, 1978) is:

\section{$52^{\prime}$ cys $A$ cys $K$ pts $H$ ptsI crr dsd $51^{\prime}$}

the $c r r$ gene of $S$. typhimurium being identical to the $E$. coli gsr gene (Parra et al., 1983a). This supports and extends the observation by Parra et al. $(1983 \mathrm{~b})$ that there is an inversion of DNA in $S$. typhimurium relative to $E$. coli. The present results indicate that cysK as well as $p t s H$ and $p t s I$ lie within the inverted region. Kingsman (1977), Kingsman \& Smith (1978) and Kingsman et al. (1978) have shown that this region of the $S$. typhimurium genome may behave in some ways as a transposon. This may account for the differences in gene order observed.

The cys $K$ promoter may prove useful for the construction of a specialized expression vector. We have demonstrated its ability to express a $\lambda$ protein, a fragment of the bEa59 gene product, in plasmids pAB65 and pAB68. Only the cysK gene product appears to be regulated by cystine 
though the cysB gene product also affects the expression of other proteins. We have no satisfactory explanation for this observation.

We thank Dr F. Sanger for allowing access to his $\lambda$ DNA sequence data whilst in preparation, Dr P. Johnson and Mr D. Reed for carrying out the ultracentrifugation experiments and Miss $M$. Mather for performing the amino acid analysis. This work was supported by the Science and Engineering Research Council, through Grant GR/B/2248.2, and was performed during the tenure of A. Boronat and F. Parra of EMBO Long-term Fellowships. We gratefully acknowledge these sources of help.

\section{REFERENCES}

Alexander, A. E. \& Johnson, P. (1949). Colloid Science, p. 293. Oxford: Oxford University Press.

Ambler, R. P. \& SCOTt, G. K. (1978). Partial amino acid sequence of penicillinase coded by Escherichia coli plasmid R6K. Proceedings of the National Academy of Sciences of the United States of America 75, 3732-3736.

Ashworth, J. M. \& Konnaerg, H. L. (1966). The anaplerotic fixation of carbon dioxide by Escherichia coli. Proceedings of the Royal Society of London B165, 179-188.

BACHMANN, B. J. \& Low, K. B. (1980). Linkage map of Escherichia coli K12, edition 6. Microbiological Reviews 44, 1-56.

BeCKer, M. A., KREDich, N. M. \& Tomitins, G. M. (1969). The purification and characterisation of $O$ acetylserine sulphydrylase-A from Salmonella typhimurium. Journal of Biological Chemistry 244, 24182427.

BirNboim, H. C. \& Doly, J. (1979). A rapid alkaline extraction procedure for screening recombinant plasmid DNA. Nucleic Acids Research 7, 1513-1523.

Bolivar, F., Rodriguez, R., Greene, P. J., Betlach, M., Heynexer, H. L., BOyer, H. W., CrosA, J. \& Falkow, S. (1977). II. Construction and characterization of new cloning vehicles, a multipurpose cloning system. Gene 2, 95-113.

Boronat, A., Jones-Mortmer, M. C. \& Kornbero, H. L. (1982). A specialized transducing phage, ApsrlA, for the sorbitol phosphotransferase of $E_{S}$ cherichia coli K12. Journal of General Microbiology 128, 605-611.

Britton, P., Murfitt, D., Parra, F., Jones-MorTIMer, M. C. \& Korneerg, H. L. (1982). Phosphotransferase-mediated regulation of carbohydrate utilization in Escherichia coli K12: identification of the products of genes on the specialised transducing

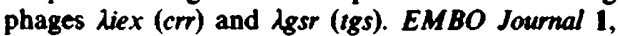
907-911.

Britton, P., Boronat, A., Hartley, D. A., JonesMortimer, M. C., Korneerg, H. L. \& PArRA, F. (1983). Phosphotransferase-mediated regulation of carbohydrate utilization in Escherichia coli $\mathrm{K} 12$ : location of the gsr (tgs) and iex (crr) genes by specialized transduction. Journal of General Microbiology 129, 349-358.

Dagert, M. \& Ehrlich, S. D. (1979). Prolonged incubation in calcium chloride improves the competence of Escherichia coli cells. Gene 6, 23-28.

DAvis, R. W., BotsteIN, D. \& Roth, J. R. (1980). Aduanced Bacterial Genetics. Cold Spring Harbor, New York: Cold Spring Harbor Laboratory.

EPP, C. (1978). Early protein synthesis and its control in bacteriophage lambda. Ph.D. thesis, University of Toronto, Canada.

FmMeL, A. L. \& Loughlin, R. E. (1977). Isolation and characterization of cys $K$ mutants of Escherichia coli K12. Joumal of General Microbiology 103, 37-43.

Henderson, P. J. F., Giddens, R. A. \& JonesMortimer, M. C. (1976). Transport of galactose, glucose and their molecular analogues by Escherichia coli K12. Biochemical Joumal 162, 309-320.

Hulanicka, M. D. Klopotowski, T. (1972). Mutants of Salmonella typhimurium resistant to triazole. Acta biochimica polonica 19, 251-260.

Hulanicka, M. D., Kredich, N. M. \& Treman, D. M. (1974). The structural gene for $O$-acetylserine sulphydrylase $A$ in Salmonella typhimurium: identity with the trzA locus. Journal of Biological Chemistry 249, 867-872.

JONES-MORTMER, M. C. (1968). Positive control of sulphate reduction in Escherichia coli: isolation, characterisation and mapping of cysteineless mutants of E. coli K12. Biochemical Journal 110, 589595.

Kingsinan, A. J. (1977). The structure of the cys $C D H I J$ region in unstable auxotrophs of Salmonella typhimurium. Molecular and General Genetics 156, 327-332.

KINGSMaN, A. J. \& SMITH, D. A. (1978). The nature of genetic instability in auxotrophs of Salmonella typhimurium requiring cysteine or methionine and resistant to inhibition by 1,2,4-triazole. Genetics 89,439 451.

Kingsman, A. J., SMith, D. A. \& Hulanicka, M. D. (1978). Genetic instability in auxotrophs of Salmonella typhimurium requiring cysteine or methionine and resistant to inhibition by 1,2,4-triazole. Genetics 89, 419-437.

Kleckner, N., BARKer, D. F., Ross, D. G. \& Botstein, D. (1978). Properties of the translocatable tetracycline-resistance element TnI0 in Escherichia coli and bacteriophage lambda. Genetics $90,427-461$.

KREDICH, N. M. (1971). Regulation of L-cysteine biosynthesis in Salmonella typhimurium. I. Effects of growth on varying sulphur sources and $O$-acetyl-Lserine on gene expression. Journal of Biological Chemistry 246, 3474-3484.

Kredich, N. M. \& ToMins, G. M. (1966). The enzymatic synthesis of L-cysteine in Escherichia coli and Salmonella typhimurium. Journal of Biological Chemistry 241, 4955-4965.

LEE, J. C. \& TMASHEFF, S. N. (1974). The calculation of partial specific volumes of proteins in guanidine hydrochloride. Archives of Biochemistry and Biophysics 165, 268-273. 
Lee, L. G., Britton, P., Parra, F., Boronat, A. \& KORNBERG, H. L. (1982). Expression of the pts $H^{+}$ gene of Escherichia coli cloned on plasmid pBR322: a convenient means for obtaining the histidine-containing carrier protein HPr. FEBS Letters 149, 288292.

LEVY, S. B. (1970). Resistance of minicells to penicillin lysis: a method of obtaining large quantities of purified minicells. Journal of Bacteriology 103, 836839.

Parra, F., Jones-Mortimer, M. C. \& Kornberg, H. L. (1983a). Phosphotransferase-mediated regulation of carbohydrate utilization in Escherichia coli K12: the nature of the iex (crr) and gsr (tgs) mutations. Journal of General Microbiology 129, 337348.

Parra, F., Britton, P., Castle, C., Jones-Mortimer, M. C. \& KORNBERG, H. L. (1983b). Two separate genes involved in sulphate transport in Escherichia coli K12. Journal of General Microbiology 129, 357358.

Perham, R. N. (1978). Techniques for determining the amino acid composition and sequence of proteins: Techniques in Protein and Enzyme Biochemistry. Edited by H. L. Kornberg, J. C. Metcalfe, D. H. Northcote, C. I. Pogson \& K. F. Tipton. Techniques in Life Sciences, vol. B110, pp. 1-39. Amsterdam \& New York: Elsevier.

REEVE, J. (1979). Use of minicells for bacteriophagedirected polypeptide synthesis. Methods in Enzymo$\log y$ 68, 493-503.

Sanderson, K. E. \& Hartman, P. E. (1978). Linkage map of Salmonella typhimurium, edition V. Microbiological Reviews 42, 471-519.

SANGER, F., Coulson, A. R., Hong, G. F., Hill, D. F. \& Petersen, G. B. (1982). Nucleotide sequence of bacteriophage $\lambda$ DNA. Journal of Molecular Biology 162, 729-773.
SchachmaN, H. K. (1959). Ultracentrifugation in Biochemistry, pp. 236-247. New York \& London: Academic Press.

SPEnCER, H. T., COllins, J. \& Monty, K. J. (1967). Sequential regulation of cysteine biosynthesis in Salmonella typhimurium. Federation Proceedings 26, 677.

SumNer-SMITH, M., Benchimol, S., MuRIALdo, H. \& BECKER, A. (1982). The ben gene of bacteriophage $\lambda$. Mapping, identification and control of synthesis. Journal of Molecular Biology 160, 1-22.

SuTCLIFFE, J. G. (1978). Complete nucleotide sequence of Escherichia coli plasmid pBR322. Cold Spring Harbor Symposia on Quantitative Biology 43, 77-90.

SzYbalski, E. H. \& SzYBalsKi, W. (1979). A comprehensive molecular map of bacteriophage lambda. Gene 7, 217-270.

Wiater, A. \& Hulanicka, M. D. (1979). Properties of cysK mutants of Escherichia coli K12. Acta biochimica polonica 26, 21-28.

Wiater, A., Filutowicz, M. \& Hulanicka, M. D. (1982). A new class of mutants of the cysB regulatory gene for cysteine biosynthesis in Salmonella typhimurium. Journal of General Micrabiology 128, 17851790.

Witholt, B., BoEkHOUT, M., BROCK, M., KINGMA, J., VAN HEERIKHUIZEN, H. \& DE LEIJ, L. (1976a). An efficient and reproducible procedure for the formation of spheroplasts from variously grown Escherichia coli. Analytical Biochemistry 74, 160-170.

Witholt, B., Van Heerikhuizen, H. \& de Leis, L. $(1976 b)$. How does lysozyme penetrate through the bacterial outer membrane? Biochimica et biophysica acta 443, 534-544.

WorCel, A. \& Burgi, E. (1974). Properties of a membrane-attached form of the folded chromosome of Escherichia coli. Journal of Molecular Biology 82, 91-105. 